\title{
Chitin Synthase in Mortierella vinacea: Properties, Cellular Location and Synthesis in Growing Cultures
}

\author{
By J. F. PEBERDY AND P. M. MOORE* \\ Department of Botany, University of Nottingham, Nottingham $N_{7} 2 R D$
}

(Received 14 November 1974; revised 7 June 1975)

\section{SUMMARY}

Chitin synthase of Mortierella vinacea was present in the 'microsomal' fraction ( $100000 \mathrm{~g}$ precipitate), the 'cell-wall' fraction ( $2000 \mathrm{~g}$ precipitate) and the 'mitochondrial' fraction (I0000 $\mathrm{g}$ precipitate). The properties of the 'microsomal' enzyme were investigated. The $\mathrm{pH}$ optimum was between 5.8 and 6.2 , and the temperature optimum was between $3 \mathrm{I}$ and $33{ }^{\circ} \mathrm{C}$. The $K_{m}$ for UDP $N$-acetyl-Dglucosamine was $\mathrm{I} .8 \mathrm{~mm}$. The enzyme was stimulated by $\mathrm{Mg}^{2+}$ and a slight stimulation was also effected by $N$-acetyl-D-glucosamine. Soluble chitodextrins were inhibitory. A pH-dependent, heat-stable inhibitor of chitin synthase activity was present in the soluble cytoplasm from the mycelium. The effects of aeration and glucose concentration on enzyme production in growing cultures were also investigated; maximum specific activity of chitin synthase was associated with the cessation of exponential growth.

\section{INTRODUCTION}

Chitin synthase (chitin-UDP acetylglucosaminyltransferase, EC. 2.4.I. I6), which catalyses the formation of chitin from UDP $N$-acetyl-D-glucosamine (UDP-GlcNAc), has been reported in many fungi (Glaser \& Brown, 1957; Jaworski, Wang \& Carpenter, 1965; Porter \& Jaworski, I966; Camargo et al. 1967; Keller \& Cabib, I971; McMurrough, Flores-Carreon \& Bartnicki-Garcia, I971; Gooday, I972; Jan, 1974). The enzyme exhibits varying properties and activities in the different taxonomic groups, but there have been few attempts to relate the synthesis of the enzyme to the patterns of mycelial growth. Activities of chitin synthase were shown to depend on culture age in Venturia inequalis (Jaworski et al. 1965) and Mucor rouxii (McMurrough et al. 197I). Similarly, Gooday (I973) demonstrated that the specific activity of chitin synthase in the fruiting bodies of Coprinus cinereus was dependent on their size and age.

This paper describes some properties of the enzyme chitin synthase of Mortierella vinacea, including its inhibition, cellular location and synthesis in growing cultures.

\section{METHODS}

Organism and culture. Mortierella vinacea strain NFI33 (University of Nottingham collection) was maintained on malt extract agar at $30^{\circ} \mathrm{C}$. Spore suspensions for inoculation of liquid cultures were prepared in distilled water using four-day-old slopes. Mycelium, for enzyme preparation, was grown in 51 Erlenmeyer flasks containing $500 \mathrm{ml}$ of Vogel's

* Present address: Department of Biochemistry, University of Alberta, Edmonton, Alberta, Canada. 
salts medium $\mathrm{N}$ (Vogel, 1956). This solution contained $(\mathrm{g} / \mathrm{l})$ : sodium citrate ${ }_{5} \mathrm{H}_{2} \mathrm{O}, 3$; $\mathrm{KH}_{2} \mathrm{PO}_{4}, 5 ; \mathrm{NH}_{4} \mathrm{NO}_{3}, 2 ; \mathrm{MgSO}_{4} \cdot 7 \mathrm{H}_{2} \mathrm{O}, 0.2$; and $5 \mathrm{ml}$ of trace element solution. The latter contained (g/100 ml): citric acid, $5 ; \mathrm{ZnSO}_{4} \cdot 7 \mathrm{H}_{2} \mathrm{O}, 5 ; \mathrm{Fe}\left(\mathrm{NH}_{4}\right)_{2}\left(\mathrm{SO}_{4}\right)_{2} \cdot 6 \mathrm{H}_{2} \mathrm{O}, \mathrm{I} ; \mathrm{CuSO}_{4}$. $5 \mathrm{H}_{2} \mathrm{O}, 0.25 ; \mathrm{MnSO}_{4} . \mathrm{IH}_{2} \mathrm{O}, 0.05 ; \mathrm{H}_{3} \mathrm{BO}_{3}, 0.05 ; \mathrm{Na}_{2} \mathrm{MoO}_{4} .2 \mathrm{H}_{2} \mathrm{O}, 0.05$. Glucose was added at $\mathrm{I} \mathrm{g} / \mathrm{I} 00 \mathrm{ml}$ and the medium adjusted to $\mathrm{pH} 6.5$. Spores were added at $10^{6} \mathrm{ml}$. The flasks were incubated at $30^{\circ} \mathrm{C}$ on a reciprocal shaker at 100 strokes $/ \mathrm{min}$. The mycelium was harvested after $24 \mathrm{~h}$ by filtration through a sintered glass filter (porosity o) and washed three times with ice-cold $50 \mathrm{mM}-\mathrm{KH}_{2} \mathrm{PO}_{4}-\mathrm{KOH}$ buffer, $\mathrm{pH} 6 \cdot 0$, containing $10 \mathrm{~mm}-\mathrm{MgCl}_{2}$ (McMurrough et al. 1971).

In some experiments the fungus was grown in a simple fermenter. Spores were prepared and inoculated as described above. For these experiments cultures were grown on modified Vogel's salts medium containing $\mathrm{NH}_{4} \mathrm{Cl}$ as the nitrogen source and glucose was added at different concentrations. The fermenter contained 31 medium and was maintained at $30{ }^{\circ} \mathrm{C}$. The cultures were agitated by a magnetic stirrer and aerated through a sparger.

Preparation of enzyme fractions. Washed mycelium was suspended in an equal volume of $0.5 \mathrm{M}-\mathrm{KH}_{2} \mathrm{PO}_{4}-\mathrm{KOH}$ buffer, $\mathrm{pH} 6.0$, containing Io $\mathrm{mm}-\mathrm{MgCl}_{2}$ and rapidly disrupted for $45 \mathrm{~s}$ in a Braun MSK homogenizer (4000 rev./min) cooled with $\mathrm{CO}_{2}$. Microscopic examination showed that at least $99 \%$ of the cells were ruptured and the contents released. After centrifuging at $2000 \mathrm{~g}$ ( $\mathrm{g}_{\text {av }}$, with swing-out rotors) for $10 \mathrm{~min}$, the pellet ('cell-wall' fraction) was resuspended in $50 \mathrm{~mm}-\mathrm{KH}_{2} \mathrm{PO}_{4}-\mathrm{KOH}$ buffer, $\mathrm{pH} 6 \cdot 0$, containing I mM- $\mathrm{MgCl}_{2}$. The supernatant was centrifuged at $10000 \mathrm{~g}$ for $10 \mathrm{~min}$ and the pellet ('mitochondrial' fraction) resuspended in buffer. The $10000 \mathrm{~g}$ supernatant was then centrifuged at $100000 \mathrm{~g}$ for $30 \mathrm{~min}$ to prepare the 'microsomal' fraction, which was also suspended in buffer. The supernatant from this centrifugation was dialysed for $4 \mathrm{~h}$ against $50 \mathrm{mM}-\mathrm{KH}_{2} \mathrm{PO}_{4}-\mathrm{KOH}$ buffer, $\mathrm{pH} 6 \cdot 0$. The other fractions were recentrifuged and resuspended twice in $50 \mathrm{mM}$ buffer, before finally storing at $-20^{\circ} \mathrm{C}$ together with the supernatant fraction.

Chitin synthase assay was based on the method described by Glaser \& Brown (I957). For most experiments the reaction mixture contained I mM-UDP-GlcNAc, 5 to Io $\mu \mathrm{Ci}$ UDP-[U-14 $\mathrm{C}] \mathrm{GlcNAc}, 20 \mathrm{mM}-\mathrm{MgCl}_{2}, 20 \mathrm{mM}-N$-acetylglucosamine (GlcNAc), $25 \mathrm{mM}$ $\mathrm{KH}_{2} \mathrm{PO}_{4}-\mathrm{KOH}$ (pH 6.0) and 'microsomal' fraction enzyme (I to $5 \mathrm{mg}$ protein), in a total volume of $50 \mu \mathrm{l}$. Mixtures were incubated at $31{ }^{\circ} \mathrm{C}$, usually for $15 \mathrm{~min}$, and the reactions were terminated by the addition of $10 \mu \mathrm{l}$ glacial acetic acid. A sample $(50 \mu \mathrm{l})$ was removed from each mixture for descending chromatography using Whatman No. I paper strips. The chromatograms were usually developed for $6 \mathrm{~h}$ in $95 \%$ ethanol-I M-acetic acid $(7: 3, v / v)$. Chitin formed during the assay was not eluted and remained at the origin of the chromatogram. This region was excised and the radioactivity measured. All assays were carried out in triplicate, with controls prepared by adding the acetic acid before the enzyme preparation. In some experiments the chromatograms were developed in I-butanolpyridine-water (6:4:3, by vol.). A Panex RTL 5-IA thin-layer scanner was used to locate the components of the mixtures. Isotope counts were determined using a Packard TriCarb liquid scintillation counter. Pieces of chromatography paper were suspended in $5 \mathrm{ml}$ scintillation fluid [0.1 g 1,4-bis-(5-phenyloxazol-2-yl) benzene and $2 \mathrm{~g} \mathrm{2,5}$-diphenyloxazole in I 1 scintillation grade toluene]; quench corrections were made. Chitin synthase activity was expressed as nmol GlcNAc incorporated $/ \mathrm{min} / \mathrm{mg}$ protein, except where stated.

Protein determinations. Protein was measured by the method of Lowry et al. (I95I) using bovine serum albumin as a standard.

Analyses on fermenter cultures. Residual glucose in the culture medium was determined by the anthrone method (Trevelyan \& Harrison, 1952) as modified by Yemm \& Willis 
(1954). Residual nitrogen was determined as ammonia using Nessler's reagent. The pH was measured using an E.I.L. meter. Dry weight determinations were made on small volumes of the cultures by vacuum filtration through previously-tared filter papers, which were then dried for $24 \mathrm{~h}$ at $105{ }^{\circ} \mathrm{C}$ before reweighing.

Preparation of soluble chitodextrins. Soluble chitodextrins were prepared by hydrolysis of pure chitin for I h with $5 \mathrm{M}-\mathrm{HCl}$ at $100{ }^{\circ} \mathrm{C}$ (Zechmeister \& Toth, I93I). Excess acid was removed by precipitation with excess $\mathrm{Ag}_{2} \mathrm{CO}_{3}$. The soluble chitodextrins were precipitated from solution with ethanol. Two fractions $\left(F_{1}\right.$ and $\left.F_{2}\right)$ were obtained using 48 and $89 \%$ $(\mathrm{v} / \mathrm{v})$ ethanol.

Chemicals. UDP-[U-14 C]GlcNAc, specific activity $200 \mathrm{mCi} / \mathrm{nmol}$, was obtained from the Radiochemical Centre, Amersham, Buckinghamshire. Chitinase (fungal) was purchased from Mann Research Laboratories Inc., New York, U.S.A.; other biochemicals were from Sigma. General chemicals, of analytical grade where possible, were from BDH.

\section{RESULTS}

Distribution of chitin synthase activity in the cellular fractions

Almost half the total chitin synthase was found in the 'cell-wall' fraction (Table I), with most of the remainder in the 'microsomal' and 'mitochondrial' fractions. However, the three particulate fractions showed similar specific activities. Further disruptions of the 'cell-wall' fraction followed by washings showed a very small decrease in the enzyme activity of the walls.

\section{Effects of storage on enzyme stability}

The activity of the 'microsomal' fraction had a half-life of 8 to 9 days, $24 \mathrm{~h}$ and $\mathrm{I} 2 \mathrm{~h}$, respectively, when stored at $-20^{\circ} \mathrm{C}$, $0^{\circ} \mathrm{C}$ or $18{ }^{\circ} \mathrm{C}$ in $25 \mathrm{mM}-\mathrm{KH}_{2} \mathrm{PO}_{4}-\mathrm{KOH}$ buffer $(\mathrm{pH} 6.0$ ) containing I mM- $\mathrm{MgCl}_{2}$. Storage at $20^{\circ} \mathrm{C}$, with subsequent thawing and refreezing every $24 \mathrm{~h}$, resulted in a reduction of the enzyme half-life to 4 to 5 days.

\section{Reaction kinetics}

From a slightly curved Lineweaver-Burk plot (Fig. 1), the apparent $K_{m}$ for UDPGlcNAc was estimated to be about $\mathrm{I} .8 \mathrm{mM}$. In further experiments the concentration of UDP-GlcNAc was maintained at I mM whilst the GlcNAc concentration was varied between $O$ and $20 \mathrm{mM}$. The addition of increasing concentrations of GlcNAc caused a slight stimulation of enzyme activity. Inclusion of the soluble chitodextrins $F_{1}$ and $F_{29}$ in the assay mixtures had an inhibitory effect (Table 2).

\section{Identification of assay product}

Reactions similar to those described in Methods were scaled up to give a final working volume of $500 \mu \mathrm{l}$, and terminated after $2 \mathrm{~h}$. Chromatography (ethanol:acetic acid) of samples from the reaction mixtures demonstrated the presence of two peaks; the first remained at the origin and the second had an $R_{F}$ value $(0.42)$ similar to the UDP-GlcNAc standard. After dialysis of the reaction mixtures against distilled water for $24 \mathrm{~h}$ at $4{ }^{\circ} \mathrm{C}$, to remove the substrate, the non-dialysable material was centrifuged at $2000 \mathrm{~g}$ for $20 \mathrm{~min}$ and finally resuspended in $0.5 \mathrm{ml}$ distilled water. Hydrolysis with concentrated $\mathrm{HCl}$ for $2 \mathrm{~h}$ at $100{ }^{\circ} \mathrm{C}$, followed by neutralization, resulted in a single product with an $R_{F}$ value $(0.59)$ equivalent to glucosamine. The effect of chitinase was tested by mixing equal volumes of the 'chitin' material with a solution of the enzyme ( $\mathrm{I} \mathrm{mg} / \mathrm{ml})$ in $50 \mathrm{mM}-\mathrm{KH}_{2} \mathrm{PO}_{4}-\mathrm{KOH}$ buffer, $\mathrm{pH} 6 \cdot 5$, for $2 \mathrm{~h}$ at $30^{\circ} \mathrm{C}$. The reaction was terminated with glacial acetic acid and 


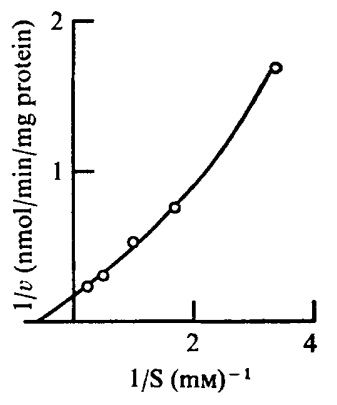

Fig. I

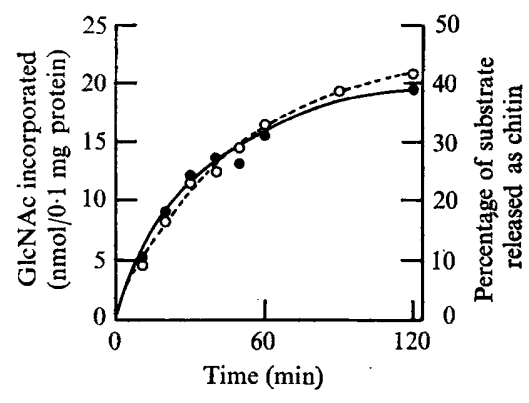

Fig. 2

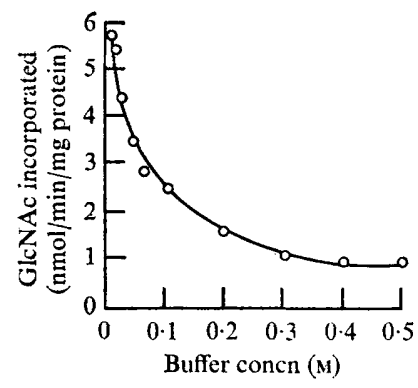

Fig. 3

Fig. I. Effect of substrate concentration on the chitin synthase activity of the 'microsomal' fraction. Results are presented as a double reciprocal plot of rate of incorporation of substrate into chitin against UDP-GlcNAc concentration. The protein concentration was $1 \cdot 94 \mathrm{mg} / \mathrm{ml}$ and the assays were terminated after $30 \mathrm{~min}$.

Fig. 2. Effect of incubation time on chitin formed by various fractions. Assay conditions were as described for the standard method except that the incubation time was varied. Substrate incorporation is expressed as $\mathrm{nmol} / 0 . \mathrm{I} \mathrm{mg}$ protein and as a percentage of substrate released as product. Protein concentrations $(\mathrm{mg} / \mathrm{ml})$ : 'microsomal' fraction (O), I.94; 'mitochondrial' fraction (O), 2.I.

Fig. 3. Effect of buffer concentration on chitin formation by the 'microsomal' fraction. The reaction conditions were as described for the standard assay except that the concentration of $\mathrm{KH}_{2} \mathrm{PO}_{4}-$ $\mathrm{KOH}$ buffer, $\mathrm{pH} 6 \cdot 5$, was varied. The protein concentration was $\mathrm{I} \cdot 94 \mathrm{mg} / \mathrm{ml}$.

Table $\mathrm{x}$. Distribution of chitin synthase in the different cellular fractions of $M$. vinacea

The fractions were prepared by centrifugation as described in Methods; each fraction was diluted to give $\mathrm{I}$ to $5 \mathrm{mg}$ protein $/ \mathrm{ml}$. Total activity is based on the activity of enzyme and amount of protein in each fraction.

$\begin{array}{lcc}\text { Fraction } & \begin{array}{c}\text { Specific activity } \\ \text { (nmol/min/mg protein) }\end{array} & \begin{array}{c}\text { Total activity } \\ (\%)\end{array} \\ \text { 'Cell-wall' } & 10 \cdot 5 & 48 \cdot 7 \\ \text { 'Mitochondrial' } & 11 \cdot 4 & 16 \cdot 3 \\ \text { 'Microsomal' } & 8 \cdot 4 & 28 \cdot 1 \\ \text { Supernatant } & 2 \cdot 3 & 6 \cdot 9\end{array}$

the neutralized mixture was chromatographed, using butanol-pyridine-water $(6: 4: 3$, by vol.) as solvent. Only $3 \%$ of the activity remained at the origin, the remainder being located as a single peak with an $R_{F}$ value (0.73) similar to that of GlcNAc.

\section{Time course of chitin formation}

After 20 min incubation, 18.9 and $16.2 \%$ of the substrate was converted to chitin by the 'mitochondrial' and 'microsomal' material, respectively. The initial rates of activity in this experiment were 6.33 and $5.2 \mathrm{nmol} \mathrm{GlcNAc}$ incorporated $/ \mathrm{min} / \mathrm{mg}$ protein for the 'mitochondrial' and 'microsomal' fractions, respectively (Fig. 2).

\section{Effect of buffer concentration and $\mathrm{pH}$}

The $\mathrm{pH}$ of the incubation mixture was varied using $25 \mathrm{mM}-\mathrm{KH}_{2} \mathrm{PO}_{4}-\mathrm{KOH}$ buffer and $50 \mathrm{~mm}$-tris- $\mathrm{HCl}$. Maximum activity was found with $\mathrm{KH}_{2} \mathrm{PO}_{4}-\mathrm{KOH}$, the optimum $\mathrm{pH}$ value being between 5.8 and 6.2. Increasing the concentration of phosphate buffer ( $\mathrm{pH} 6.5$, 
Table 2. The effect of soluble chitodextrins on chitin synthase

'Microsomal' fractions were used in the assays, which were carried out as described in Methods.

\begin{tabular}{|c|c|c|}
\hline \multirow{2}{*}{$\begin{array}{l}\text { Chitodextrin } \\
\text { concn } \\
(\mathrm{mg} / \mathrm{ml})\end{array}$} & \multicolumn{2}{|c|}{$\begin{array}{l}\text { Chitin synthase activity* } \\
\text { (nmol GlcNAc incorporated } / \mathrm{min} / \mathrm{mg} \text { protein }\end{array}$} \\
\hline & Chitodextrin $F_{1}$ & Chitodextrin $\mathrm{F}_{2}$ \\
\hline 0 & $2.7 \pm 0.11$ & $2 \cdot 7 \pm 0 \cdot 1 \mathrm{I}$ \\
\hline $2 \cdot 5$ & $2 \cdot 0 \pm 0 \cdot 15$ & $1 \cdot 9 \pm 0.13$ \\
\hline $5 \cdot 0$ & $I \cdot 4 \pm 0 \cdot 20$ & $0.9 \pm 0.4 I$ \\
\hline
\end{tabular}

Table 3. Effect of cations on chitin synthase activity

\begin{abstract}
Assays were carried out using the standard procedure described in Methods; the 'microsomal' fraction was used as the source of enzyme. The reaction mixture contained $0.4 \mathrm{mM}-\mathrm{MgCl}_{2}$ and other cations, added as chlorides, at a final concentration of $10 \mathrm{~mm}$.
\end{abstract}

\begin{tabular}{|c|c|c|}
\hline \multirow[b]{2}{*}{ Cation } & \multicolumn{2}{|c|}{ Enzyme activity } \\
\hline & $\begin{array}{l}\text { GlcNAc incorporation } \\
\text { (nmol } / \mathrm{min} / \mathrm{mg} \text { protein) }\end{array}$ & $\begin{array}{l}\text { Percentage of } \\
\text { control level }\end{array}$ \\
\hline None (control) & 0.90 & 100 \\
\hline $\mathrm{Fe}^{3+}$ & $0 \cdot 26$ & $28 \cdot 5$ \\
\hline $\mathbf{M n}^{2+}$ & 0.80 & $88 \cdot 0$ \\
\hline $\mathbf{M g}^{2+}$ & $1 \cdot 88$ & $206 \cdot 6$ \\
\hline $\mathrm{Ca}^{2+}$ & 0.36 & $39 \cdot 6$ \\
\hline $\mathrm{Na}^{+}$ & 0.89 & $97 \cdot 8$ \\
\hline $\mathbf{K}^{+}$ & 0.78 & $85 \cdot 7$ \\
\hline $\mathrm{Co}^{2+}$ & $1 \cdot 02$ & $112 \cdot 1$ \\
\hline $\mathrm{Cu}^{2+}$ & 0.48 & $52 \cdot 7$ \\
\hline $\mathrm{Zn}^{2+}$ & 0.15 & $16 \cdot 5$ \\
\hline $\mathrm{NH}_{4}{ }^{+}$ & 0.85 & 93.4 \\
\hline $\mathbf{B a}^{2+}$ & 0.35 & $38 \cdot 5$ \\
\hline
\end{tabular}

containing $20 \mathrm{mM}-\mathrm{MgCl}_{2}$ ) from $\mathrm{I}$ to $500 \mathrm{mM}$, caused an inhibition of the chitin synthase activity of the 'microsomal' fraction (Fig. 3). The pH of the final reaction mixture was corrected in each case. The $25 \mathrm{~mm}$ buffer was selected for use, despite a slight inhibitory effect, because at lower concentrations buffering capacity was severely reduced.

\title{
Effect of different cations on chitin synthase activity
}

The influence of several metallic ions was investigated and only $\mathrm{Mg}^{2+}$ showed a marked stimulation in activity over the control (Table 3). $\mathrm{Co}^{2+}$ showed a slight increase in activity, but $\mathrm{Zn}^{2+}, \mathrm{Fe}^{2+}, \mathrm{Ba}^{2+}$, and $\mathrm{Ca}^{2+}$ caused the greatest inhibition of chitin formation. Variation in $\mathrm{MgCl}_{2}$ concentration between 0.6 and $100 \mathrm{mM}$ showed an increase in activity up to $20 \mathrm{~mm}$, after which there was a progressive inhibition of the enzyme.

\section{Effect of temperature}

Standard reaction mixtures were incubated at various temperatures for $15 \mathrm{~min}$. Chitin synthase activity was maximal between $3 \mathrm{I}$ and $33{ }^{\circ} \mathrm{C}$.

Chitin synthase inhibitor in soluble cytoplasm

The presence of a soluble cytoplasmic inhibitor of chitin synthase activity in vitro was observed. Mycelium was homogenized without buffer and submitted to differential centri- 
Table 4. The effect of $p H$ on the inhibition of chitin synthase activity by soluble cytoplasm

\begin{abstract}
Enzyme assays using the 'microsomal' fraction were carried out according to the procedure described in Methods. The $100000 \mathrm{~g}$ supernatant was added at a final concentration, as protein, of $\mathrm{I} \mathrm{mg} / \mathrm{ml}$.
\end{abstract}

$\begin{array}{lccc}\begin{array}{c}\text { pH } \\ \text { value }\end{array} & \begin{array}{c}\text { Without } \\ \text { cytoplasm (A) }\end{array} & \begin{array}{c}\text { With } \\ \text { cytoplasm (B) }\end{array} & \begin{array}{c}\text { Enzyme activity } \\ \text { Relative } \\ \text { activity } \\ \text { (B/A) }\end{array} \\ 5.5 & 4.0 & 4.4 & 1 \cdot 10 \\ 5.75 & 4.0 & 4.2 & 1.05 \\ 6.0 & 4.2 & 3.5 & 0.83 \\ 6.2 & 3.1 & 2.5 & 0.81 \\ 6.55 & 1.9 & 1.5 & 0.79 \\ 6.75 & 1.3 & 1.7 & 0.76 \\ 7.0 & 1.2 & 0.7 & 0.58 \\ 7.25 & 0.7 & 0.3 & 0.43 \\ 7.5 & 0.6 & 0.2 & 0.33\end{array}$

fugation as described in Methods. The $100000 \mathrm{~g}$ supernatant was added to the standard assay mixture containing the 'microsomal'-fraction enzyme. The inhibitor activity was not lost by heating to $100^{\circ} \mathrm{C}$ or by dialysis against cold buffer. Scans of assay chromatograms showed only two peaks, corresponding to substrate and chitin, indicating that the inhibitor prevented product formation and did not cause product breakdown. The inhibitory effect of the cytoplasmic component was found to be $\mathrm{pH}$-dependent. Assay mixtures containing $25 \mathrm{mM}-\mathrm{KH}_{2} \mathrm{PO}_{4}-\mathrm{KOH}$ buffer over the range $\mathrm{pH} 5.5$ to 7.5 were set up and the $100000 \mathrm{~g}$ supernatant was added at a concentration of I $\mathrm{mg}$ protein $/ \mathrm{ml}$. Inhibition was found to increase linearly up to $\mathrm{pH} 7.5$ (Table 4 ).

\title{
Chitin synthase activities of $M$. vinacea in a fermenter under different growth conditions
}

In an attempt to relate chitin synthase production to growth of $M$. vinacea, the fungus was grown in a batch fermenter with different rates of aeration and with different medium compositions. The results are shown in Fig. 4. Halving the aeration rate (Fig. $4 a$ compared with Fig. $4 b$ ) markedly affected the utilization of glucose and about $45 \%$ of the substrate remained in the medium when the culture entered the stationary phase. At the higher rate of aeration the glucose was rapidly consumed and appeared to be the nutrient limiting extent of growth. The substrate was rapidly removed from the low-glucose medium (Fig. $4 c$ ), again indicating limitation of growth. The specific growth rates during exponential growth, calculated from logarithmic plots, were: high glucose-high aeration, $0.28 \mathrm{~h}^{-1}$; high glucose-low aeration, $0.18 \mathrm{~h}^{-1}$; low glucose, $0.25 \mathrm{~h}^{-1}$. Biomass, at the maximum population phase, was greatest with high glucose and high aeration; reduced aeration halved the mycelial yield and low glucose reduced it to about $25 \%$ of that on the highglucose medium. Chitin synthase, expressed as specific activity or as total activity, showed broadly similar patterns under all conditions of growth. Maximum specific activity of the enzyme was observed at the end of exponential growth. 

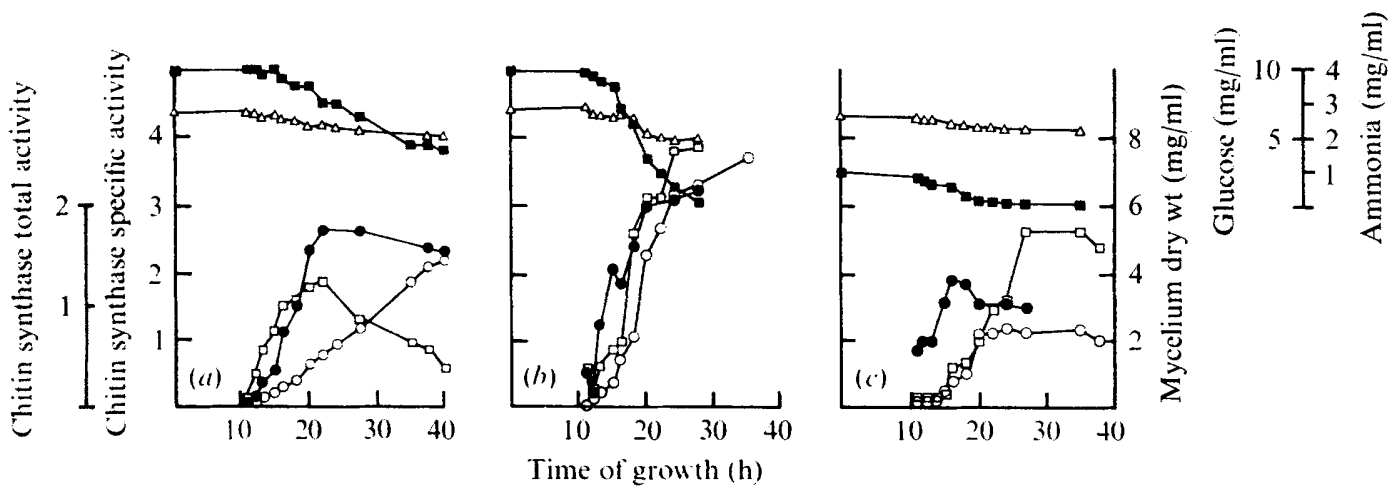

Fig. 4. Chitin synthase production by $M$. vinacea in batch fermenter culture. $\bigcirc$, Mycelium dry weight $(\mathrm{mg} / \mathrm{ml}) ; 0$, chitin synthase, total activity; $\square$, chitin synthase, specific activity; $\mathbf{n}$, residual glucose in culture medium; $\triangle$, residual ammonia in culture medium. (a) The culture medium was supplemented with glucose $(10 \mathrm{~g} / \mathrm{l})$ and ${ }^{\prime} \mathrm{NH}_{4} \mathrm{Cl}(2 \cdot 6 \mathrm{~g} / \mathrm{l})$ and the culture was aerated at $31 / \mathrm{min}$. (b) The medium was as in (a), but aeration was $6 \mathrm{l} / \mathrm{min}$. (c) The medium was supplemented with glucose $(2 \cdot 5 \mathrm{~g} / \mathrm{l})$ and $\mathrm{NH}_{4} \mathrm{Cl}(2 \cdot 6 \mathrm{~g} / \mathrm{l})$ and the culture was aerated at $6 \mathrm{l} / \mathrm{min}$.

\section{DISCUSSION}

The high activity of chitin synthase in the $2000 \mathrm{~g}$ 'cell-wall' fraction of $M$. vinacea corresponds with the findings in the Mucorales, Mucor rouxii (McMurrough et al. 197I), Phycomyces blakesleeanus (Jan, 1974) and Cunninghamella elegans (Moore \& Peberdy, 1975). In other organisms studied (Glaser \& Brown, 1957; Jaworski et al. I965; Porter \& Jaworski, 1966; Camargo et al. 1967) the enzyme was said to be located mainly in the mitochondrial and 'microsomal' fractions, but no reference to the examination of 'cell-wall' fractions was made by these authors.

On the basis of their findings with $M$. rouxii, McMurrough et al. (197I) proposed that the $100000 \mathrm{~g}$ 'microsomal' fraction is the site of chitin synthase formation before its migration to its site of action in the cell wall. The difficulty of removing chitin synthase from the 'cell-wall' fractions of $M$. vinacea and $M$. rouxii (McMurrough et al. 197I) suggests that the enzyme is bound to the wall. However, electron micrographs of wall fractions of Phycomyces blakesleeanus (Jan, 1974) show high contamination of the walls with attached membranous material. A membranous location for chitin synthase in the yeast-form of $M$. rouxii is now indicated by the work of Ruiz-Herrera \& Bartnicki-Garcia (1974). It is hoped that future studies on chitin synthase in protoplasts of $M$. vinacea will also help to elucidate the nature of the relationship between the enzyme and the hyphal wall.

Porter \& Jaworski (1966) suggested that freezing and thawing of chitin synthase fractions may release inhibitor or hydrolytic enzymes which act upon the substrate or the chitin formed. The presence of activators and inhibitors of chitin synthase have subsequently been demonstrated in yeast cells (Cabib \& Keller, I97I ; Cabib \& Ulane, I973 $a, b$ ). The presence of a heat-stable, $\mathrm{pH}$-dependent inhibitor of chitin synthase, similar to that found in $M$. vinacea, has been reported in $M$. rouxii (McMurrough \& Bartnicki-Garcia, 1973) and it has been purified as a protein of molecular weight 8500 from Saccharomyces cerevisiae (Ulane \& Cabib, 1974). Activators of chitin synthase have not as yet been isolated from filamentous fungi, although activation by the addition of proteases has been demonstrated in M. rouxii (McMurrough \& Bartnicki-Garcia, 1973) and Aspergillus nidulans (N. R. Ryder, personal communication). 
The formation of diacetylchitobiose as an intermediate in chitin synthesis has been reported in Blastocladiella emersonii (Camargo et al. 1967), and diacetylchitobiose was formed in place of chitin in the presence of low UDP-GlcNAc concentrations. In $M$. vinacea we did not detect diacetylchitobiose but this may have been due to the relatively large amounts of UDP-GlcNAc used (50 to $100 \mathrm{nmol} /$ assay, compared with approximately $2 \mathrm{nmol}$ used with $B$. emersonii). On the other hand, with $M$. rouxii, diacetylchitobiose was detected only with high concentrations of UDP-GlcNAc (McMurrough et al. 1971).

Identification of the chromatographically-immobile substance as chitin was confirmed by its hydrolysis with concentrated $\mathrm{HCl}$ to glucosamine, and by the action of chitinase upon it, which yielded GlcNAc as the sole product.

In chitin synthesis, GlcNAc and soluble chitodextrins have been described as activators (Glaser \& Brown, 1957; Jaworski et al. 1965; Porter \& Jaworski, 1966). Activation was also found to be induced by $N$-acetyl chitodextrins in $M$. rouxii (McMurrough \& BartnickiGarcia, 197I) and by mannose, cellobiose, glucose and glycerol (Keller \& Cabib, 197I) in S. cerevisiae. GlcNAc is thought to bear the role of an allosteric effector (Glaser \& Brown, 1957), although Camargo et al. (1967) proposed a second role as that of chitin initiator. Activation of $M$. vinacea chitin synthetase by GlcNAc was low compared with other organisms (Glaser \& Brown, 1957; Porter \& Jaworski, 1966; McMurrough \& Bartnicki-Garcia, 1971). Soluble chitodextrins are thought to behave as primers (Glaser \& Brown, 1957). In our investigations soluble chitodextrins were found to behave as inhibitors of chitin synthesis, leading to large reductions in net product formation. Similar results were reported with S. cerevisiae (Keller \& Cabib, 197I) and C. elegans (Moore \& Peberdy, 1975).

In growing hyphae the tips are the sites of wall synthesis (Bartnicki-Garcia \& Lippman, 1969; Grove \& Bracker, 1970; Gooday, 1971), and the increase in specific activity of chitin synthase during exponential growth may correlate with the increase of growing points due to branching, which occurs during this phase. The decrease in specific activity during the later stages of growth may be due to protein turnover or the formation of new enzyme coupled with a decline in the number of new growth points. The involvement of the cytoplasmic inhibitor and of proteases in releasing activated chitin synthase in growing cultures is not yet known; it is likely they play a very complex regulatory role.

This work forms part of a thesis submitted by P.M.M. to the University of Nottingham for the degree of Ph.D.

\section{REFERENCES}

BARTNICKI-GARCIA, S. \& LIPPMAN, E. (1969). Fungal morphogenesis: cell wall construction in Mucor rouxii. Science, Washington 165, 302-304.

CABIB, E. \& Keller, F. A. (197I). Chitin and yeast budding. Allosteric inhibition of chitin synthetase by a heat stable protein from yeast. Journal of Biological Chemistry 246, I67-173.

CABIB, E. \& UlANE, R. (1973a). Chitin synthetase activating factor from yeast, a protease. Biochemical and Biophysical Research Communications 50, 186-191.

CABIB, E. \& Ulane, R. (1973b). Yeast chitin synthetase. Separation of zymogen from its activating factor and recovery of the latter in the vacuole fraction. Journal of Biological Chemistry 248, 145I-1458.

Camargo, E. O., Dietrich, C. P., Sonneborn, D. \& Strominger, J. L. (1967). Biosynthesis of chitin in spores and growing cells of Blastocladiella emersonii. Journal of Biological Chemistry 242, 3I 2 I-3I 28.

GlASER, L. \& BROWN, D. H. (1957). The synthesis of chitin in cell free extracts of Neurospora crassa. Journal of Biological Chemistry 228, 729-742.

GoodAy, G. W. (1971). An autoradiographic study of hyphal growth of some fungi. Journal of General Microbiology 67, 125-133.

Gooday, G. W. (1972). The role of chitin synthetase in the elongation of fruiting bodies of Coprinus cinerus. Journal of General Microbiology 73, xxi. 
Gooday, G. W. (1973). Activity of chitin synthetase during the development of fruiting bodies of the toadstool Coprinus cinerus. Biochemical Society Transactions 1, I 105-I 107.

Grove, S. N. \& BrACKer, C. E. (1970). Protoplasmic organization of hyphal tips among fungi: vesicles and Spitzenkörper. Journal of Bacteriology 104, 989-1009.

JAN, Y. N. (1974). Properties and cellular localization of chitin synthetase in Phycomyces blakesleeanus. Journal of Biological Chemistry 249, 1973-1979.

JAWORSK I, E. G., WANG, L. C. \& CARPENTER, W. D. (1965). Biosynthesis of chitin in cell-free extracts of Venturia inequalis. Phytopathology 55, $1309-1312$.

Keller, F. A. \& CABIB, E. (1971). Chitin and yeast budding: properties of chitin synthetase from Saccharomyces carlsbergensis. Journal of Biological Chemistry 246, $160-166$.

Lowry, O. H., Rosebrough, N. J., Farr, A. L. \& Randall, R. J. (1951). Protein measurement with the Folin phenol reagent. Journal of Biological Chemistry 193, 265-275.

MCMurrough, I. \& Bartnicki-Garcia, S. (I97I). Properties of a particulate chitin synthetase from Mucor rouxii. Journal of Biological Chemistry 246, 4008-4016.

MCMURRough, I. \& BARTNICKI-Garcia, S. (1973). Inhibition and activation of chitin synthesis by Mucor rouxii cell extracts. Archives of Biochemistry and Biophysics 158, 812-816.

McMurrough, I., Flores-Carreon, A. \& Bartnicki-Garcia, S. (1971). Pathway of chitin synthesis and cellular localization of chitin synthetase in Mucor rouxii. Journal of Biological Chemistry 246, 3999-4007.

MOORE, P. M. \& Pegerdy, J. F. (1975). Biosynthesis of chitin by particulate fractions from Cunninghamella elegans. Microbios. (In the Press.).

PorTer, C. A. \& JAWORSKI, E. G. (1966). The synthesis of chitin by particulate preparations of Allomyces macrogynus. Biochemistry 5, 1 149-1 154.

Ruiz-HerRera, J. \& Bartnicki-GarCiA, S. (1974). Synthesis of cell wall microfibrils in vitro by a 'soluble' chitin synthetase from Mucor rouxii. Science, New York 186, 357-359.

TreVelyan, W. E. \& Harrison, J. S. (1952). Studies in yeast metabolism. I. Fractionation and microdetermination of cell carbohydrates. Biochemical Journal 50, 298-303.

UlANE, R. E. \& CABIB, E. (1974). The activating system of chitin synthetase from Saccharomyces cerevisiae: purification and properties of an inhibitor of the activating factor. Journal of Biological Chemistry 249, 3418-3422.

VoGEL, H. J. (1956). A convenient growth medium for Neurospora (medium N). Microbial Genetics Bulletin $13,42-43$.

Yeмm, E. W. \& Willis, A. J. (1954). Estimation of carbohydrates in plant extracts by anthrone. Biochemical Journal 57, 508-514.

ZeChmeister, L. \& Toth, G. (1931). Zur Kenntnis der Hydrolysis von Chitin mit Salzsäure. Berichte der Deutschen chemischen Gesellschaft 64, 2028-203I. 